\title{
Statistical Evaluation of the Impact of Lending on the Consumption of Russian Farms in the Context of Macroeconomic Shocks
}

\author{
Ludmila Nivorozhkina \\ Rostov State University of Economics \\ Rostov-on-Don, Russia \\ E-mail: lin45@mail.ru
}

\author{
Tatiana Toropova \\ Rostov State University of Economics \\ Rostov-on-Don, Russia \\ E-mail: ttoropova@mail.ru
}

\begin{abstract}
The article proposes and implements an integrated approach that allows to identify the specifics of the socio-economic situation of households paying out consumer loans, including loans to pay for education. Analysis conducted taking into account periods of macroeconomic shocks. A mechanism for intervening in lending to household consumer expenditures is presented, and a mechanism for smoothing consumption in situations of growth and the burden of macroeconomic crises is revealed. Using econometric methods, it has been shown that monetary expenditures, rather than income, are an adequate indicator of household welfare. The selection of the lack of influence on the credit behavior of individual characteristics (gender, age, education, etc.).
\end{abstract}

Keywords—households; credit load; credit behavior; expense

\section{INTRODUCTION}

The modern Russian market of credit services for the population began to take shape in the late 1980's, when the first cooperative and then commercial banks were created. The beginning of the 2000's was marked by an accelerated growth in the range of banking services, including debit bank cards and consumer loans. After banks, credit cooperatives and microfinance organizations came to the consumer lending market. However, the emergence of new players in the credit market is more likely a consequence of the intensification of consumer lending, which occurs during periods of economic growth. Conversely, during periods of financial crisis, there is a slowdown in the growth rate of consumer lending.

Thus, the economic growth that started since the beginning of the 2000's led to an increase in household debt to credit institutions by almost 12 times. The financial crisis of 2008 slowed down the growth rate of lending. From September 2007 to September 2008, the volume of bank debt grew only 1.5 times, and since autumn 2008 , in response to the signals of the global financial crisis, the credit activity of the population declined - the total debt from November 2008 to May 2009 decreased by $9 \%$. Accelerated growth in lending began again in 2010. As of the beginning of 2013, loans to individuals reached $15.6 \%$ of the total assets of the banking sector of the Russian Federation, 12.4\% of GDP and $19.8 \%$ of the population's cash income. [1]
New economic realities in which Russia found itself in 2014, when a sharp jump in exchange rates, a fall in oil prices and sanctions from the West led to a reduction in real incomes of the population, a fall in the growth rate of lending to the population, and an increase in the level of overdue loans. As of February 1, 2014, total debt of individuals on loans amounted to about 9.9 trillion. rubles, which was approximately equal to 67,500 rubles for each resident of Russia. According to the Bank of Russia on September 1, 2018, the volume of loans issued to individuals amounted to 13.9 trillion rub., the share of overdue debt decreased slightly and amounted to $6.3 \%$, which indirectly indicates Russia's entry into the period of recovery economic growth. $[2,3]$

During the crisis, incomes of the population and the level of employment are falling, so people who already have loans start experiencing difficulties with payments on them, and those people who have not had loans, if possible, avoid taking loans. As a result, there is a change in both the credit strategies of the population and the strategies for current consumption.

Repaying the debt for a loan for a certain period reduces the disposable money income of the household and the amount of funds that it is able to spend on all the remaining needs. As a result, often the utility of a good purchased from a loan or a service becomes very doubtful, and the credit load can become an unbearable burden. Although credit organizations apply procedures for checking the financial position of the borrower, it is often quite common practice when the borrower submits documents that inflate its disposable income. The situation is aggravated by the fact that for many types of consumer loans and for microcredits, no documents confirming income are required, only a passport must be presented. Such loans are resorted to by households that are not creditworthy from the point of view of formal inspections, and the full cost of such loans is highest due to overvalued interest rates on them, as well as significant risks of their delay or non-repayment.

The need to repay loans can cause households to reduce the consumption of vital foods, start saving on food and other vital needs. [4] 
How does the credit load affect consumer spending on Russian households and has the nature of consumption changed at different stages of the macroeconomic cycle depending on the credit load? Such an approach has an economic meaning and creates the basis for the development of a policy of harmonizing the interests of financial institutions and the population.

\section{METHODS}

To answer the question, regression models for 2006, 2008, 2009, 2012 and 2014 were specified and evaluated. The frequency of analysis is related to the fact that 2006 is the initial year of observation, 2008 and 2009 are marked by a financial crisis and two years were analyzed to determine the possible delay in household response to the crisis, 2014 became the starting point of a new economic crisis.

The modeling was carried out on the basis of the data of the project "Russian monitoring of the economic situation and public health of the National Research University Higher School of Economics" [5].

The logarithm of per capita consumer spending was taken as the dependent variable. The general form of the equation in this case is written as:

$$
\ln Y=\alpha+\sum_{i} \beta_{i} \cdot X_{i}+\sum_{j} \gamma_{j} \cdot D_{j}
$$

Where $X_{i}$ are quantitative variables, $D_{j}$ are binary variables. The interpretation of the coefficients $\gamma_{j}$ and $\beta_{i}$ is carried out in terms of percentage effects and elasticities.

To account for the credit load we will form two coefficients of the current credit load.

The first coefficient is calculated by dividing the amount spent over the past 30 days to repay the loan, return of loans, and household cash expenditures for the same period.

The second coefficient is obtained by dividing the amount spent over the past 30 days to repay the loan, return of loans, and disposable resources of households.

For the selected periods, two sets of models are evaluated. The sets of models differ only in coefficients of the first and second types.

What is the reason for choosing regressors in models? The variation in consumption can be affected by the sociodemographic characteristics of the household, household's income, and place of residence.

Many households tell the amount of available resources is lower than the amount of expenses. Perhaps households have sources of income that they don't want to talk about. To take into account this fact, a variable was formed that takes a value equal to one if the current cash expense in the household exceeded available resources and was zero in another case.

Also in the analysis of credit behavior it is important to take into account the intensity of credit behavior, namely, the number of loans that the household pays. For the purposes of the analysis, a variable was formed that takes a value equal to one if the household pays one loan, and zero if it's greater.

The purpose of the loan is also significant for the analysis of credit behavior variable. Since the purpose of the loan is known only for those households that took out a loan during the past 12 months, further analysis of credit activity was carried out only for them. The model uses the following classification of loans:

- mortgage loan for the purchase of housing, real estate;

- car;

- others.

Other types of loans include consumer loans in a bank for any purpose; to purchase a specific product in the store; educational loans; to pay for a specific service in the company. The main share of other loans is loans for purchases and consumer loans.

\section{RESULTS}

The results of the modeling with the credit load coefficient calculated as the ratio of loan repayments to household cash expenditures are presented in "Table I". The values of the model coefficients for different periods found similar trends consistent with the patterns of consumer behavior.

Residents of regional centers spent relatively more on individual consumption. At the same time, households in the cities of regional subordination in the crisis of 2008 and 2009 in comparison with regional centers, consumer spending was reduced even more: by approximately $13.2 \%$ and $19.8 \%$, respectively. In 2012, this gap in consumer spending decreased to $11.2 \%$, and even decreased slightly in 2014 $10.4 \%$. The largest gap in consumer spending for villages. In 2009 , it rose to a record high of $30.6 \%$, then dropped to $22.0 \%$ in 2012 and began to grow in $2014-23.8 \%$. Thus, the impact of the crisis reduces consumer spending, especially in cities of regional subordination and villages.

Reducing the position of the household on the income scale leads to a reduction in consumer spending. Compared with the third quintile, household consumption expenses in the first quintile in 2006 were $40.8 \%$ lower, in 2009 it reached $48.9 \%$, then decreased in 2012 to $43.2 \%$ and started to grow again and reached $47.4 \%$ in 2014 . As for the second quintile, there is no such clear tendency here, but in 2008 an increase in the negative gap is noticeable. The fourth and fifth quintiles naturally have higher consumer spending. For the fourth quintile, there is a noticeable narrowing of the gap with the third in both in 2008, and in 2009, and in 2014.

The same trend is characteristic of the fifth quintile. That is, higher-income households react to crisis periods more sensitively, relatively reducing consumer spending. So, if the household in 2006 was in the fifth quintile, then its consumer spending, compared with the consumer spending of households in the third quintile, was $68.3 \%$ more. However, by 2014 this gap was reduced to $57.4 \%$. Thus, during the investigated period of time in crisis periods in poor 
households (first quintile) the gap in consumer spending increased, they began to spend relatively less, that is, they became poorer.

The reduction in the gap between the fifth and third quintile during crisis periods also indicates that they reduced their expenses. In terms of percentage effects, the reduction in the fifth quintile is greater than in the first, but this can be explained by the fact that the consumer basket in the first quintile is close to the minimum and there are fewer resources to reduce costs.

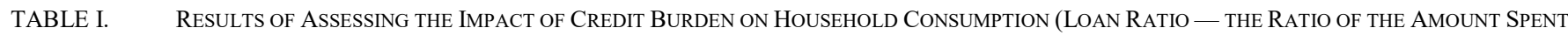
OVER THE PAST 30 DAYS TO REPAY THE LOAN, THE RETURN OF LOANS, TO THE HOUSEHOLD CASH EXPENDITURES)

\begin{tabular}{|c|c|c|c|c|c|}
\hline \multirow{2}{*}{ Variables } & \multicolumn{5}{|c|}{ Year } \\
\hline & 2006 & 2008 & 2009 & 2012 & 2014 \\
\hline \multicolumn{6}{|c|}{ Quintile of household's income (I) } \\
\hline I & $-0,408^{\mathrm{a}}$ & $-0,337^{\mathrm{a}}$ & $-0,489^{\mathrm{a}}$ & $-0,432^{\mathrm{a}}$ & $-0,474^{\mathrm{a}}$ \\
\hline II & $-0,151^{\mathrm{a}}$ & $-0,213^{\mathrm{a}}$ & $-0,205^{\mathrm{a}}$ & $-0,208^{a}$ & $-0,203^{\mathrm{a}}$ \\
\hline IV & $0,320^{\mathrm{a}}$ & $0,283^{\mathrm{a}}$ & $0,172^{\mathrm{a}}$ & $0,227^{\mathrm{a}}$ & $0,168^{\mathrm{a}}$ \\
\hline $\mathrm{V}$ & $0,683^{\mathrm{a}}$ & $0,688^{\mathrm{a}}$ & $0,640^{\mathrm{a}}$ & $0,653^{\mathrm{a}}$ & $0,574^{\mathrm{a}}$ \\
\hline \multicolumn{6}{|c|}{ Type of settlement (regional center) } \\
\hline City & $-0,084^{b}$ & $-0,132^{\mathrm{a}}$ & $-0,198^{\mathrm{a}}$ & $-0,112^{\mathrm{a}}$ & $-0,104^{\mathrm{a}}$ \\
\hline Urban settlement & $-0,082$ & $-0,112$ & $-0,113$ & $-0,103^{b}$ & 0,027 \\
\hline Village & $-0,264^{\mathrm{a}}$ & $-0,278^{\mathrm{a}}$ & $-0,306^{\mathrm{a}}$ & $-0,220^{\mathrm{a}}$ & $-0,238^{\mathrm{a}}$ \\
\hline \multicolumn{6}{|c|}{ Demographic type of household (Households without children) } \\
\hline Lonely & $0,387^{\mathrm{a}}$ & $0,339^{\mathrm{a}}$ & $0,326^{\mathrm{a}}$ & $0,213^{\mathrm{a}}$ & $0,263^{\mathrm{a}}$ \\
\hline Households with children & 0,071 & $-0,001$ & $-0,074$ & 0,021 & 0,060 \\
\hline $\begin{array}{l}\text { Single-parent families and other types of } \\
\text { households }\end{array}$ & 0,024 & 0,021 & 0,061 & 0,060 & 0,081 \\
\hline The number of children up to 3 years & $-0,146^{b}$ & $-0,173$ & $-0,118^{b}$ & $-0,066^{b}$ & $-0,045$ \\
\hline - from 3 to 7 years & $-0,147^{b}$ & $-0,049$ & 0,008 & $-0,123^{\mathrm{a}}$ & $-0,054$ \\
\hline - from7to18years & $-0,094^{\mathrm{b}}$ & $-0,040$ & 0,018 & $-0,043^{\mathrm{c}}$ & $-0,059$ \\
\hline Number of pensioners & $-0,106^{\mathrm{a}}$ & $-0,107^{a}$ & $-0,063^{\mathrm{a}}$ & $-0,083^{\mathrm{a}}$ & $-0,114^{\mathrm{a}}$ \\
\hline \multicolumn{6}{|c|}{ Types of loans (consumer and others) } \\
\hline Mortgage & $0,158^{\mathrm{b}}$ & $-0,012$ & $0,150^{\mathrm{b}}$ & 0,089 & 0,029 \\
\hline Car & $0,334^{\mathrm{a}}$ & $0,269^{b}$ & $0,242^{\mathrm{a}}$ & $0,239^{\mathrm{a}}$ & $0,290^{\mathrm{a}}$ \\
\hline \multicolumn{6}{|c|}{ The number of loans (more than one) } \\
\hline One loan & $-0,114^{\mathrm{b}}$ & $-0,070$ & $-0,035$ & 0,053 & $-0,207^{b}$ \\
\hline Credit load & $-3,030^{\mathrm{a}}$ & $-2,243^{a}$ & $-2,566^{\mathrm{a}}$ & $-2,561^{\mathrm{a}}$ & $-2,647^{\mathrm{a}}$ \\
\hline Credit load square & $2,361^{\mathrm{a}}$ & $0,996^{\mathrm{c}}$ & $1,520^{\mathrm{b}}$ & $1,433^{\mathrm{a}}$ & $1,491^{\mathrm{b}}$ \\
\hline Cashexpenses $>$ disposableresources & $0,529^{\mathrm{a}}$ & $0,558^{\mathrm{a}}$ & $0,488^{\mathrm{a}}$ & $0,508^{\mathrm{a}}$ & $0,415^{\mathrm{a}}$ \\
\hline Const. & 8,622 & 8,974 & 9,101 & 9,475 & 9,830 \\
\hline Pseudo $\mathrm{R}^{2}$ & 0,583 & 0,604 & 0,629 & 0,581 & 0,570 \\
\hline
\end{tabular}

How does the demographic component affect consumer spending? During the study period, compared to households without children, the lonely have consistently reduced the gap in consumer spending compared to households without children: from $38.7 \%$ in 2006 to $26.3 \%$ in 2014. An interesting trend is that single-parent families and other types of households are constantly increasing the share of consumer spending, which may be due, among other things, to improving the quality of social support. This thesis can be indirectly confirmed by the fact that the presence of children in the household in 2006 statistically significantly reduced their consumer spending compared to other families, and by 2014, the percentage effects decreased and became statistically insignificant.

The presence of pensioners and the increase in their number in the household as compared to households without pensioners reduces consumer spending.

The objectives of lending in different ways affect consumer spending. The presence in the household of a mortgage loan statistically significantly affected the presence of higher consumer spending compared to other types of loans only in 2006 and 2009. The presence of a car loan in a household indicates that consumer spending is higher in them, that is, it is more affluent households. Having more than one loan in a household does not significantly affect consumer spending.

In households, where expenditures are higher than disposable resources, consumer spending was significantly higher. The higher the current credit load, the lower consumer spending.

In the next block of models in "Table II", only one, but the key variable is changed: the credit load. Now it is calculated as the ratio of the amount spent over the past 30 days to repay the loan, the return of loans to the available resources of the household for the same period. 


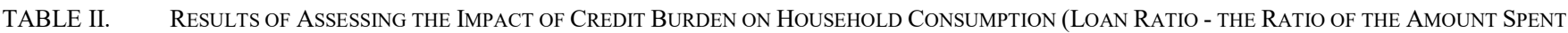
OVER THE PAST 30 DAYS TO REPAY THE LOAN, THE RETURN OF LOANS, TO THE AVAILABLE RESOURCES OF THE HOUSEHOLD)

\begin{tabular}{|c|c|c|c|c|c|}
\hline \multirow{2}{*}{ Variables } & \multicolumn{5}{|c|}{ Year } \\
\hline & 2006 & 2008 & 2009 & 2012 & 2014 \\
\hline \multicolumn{6}{|c|}{ Quintile of household's income (I) } \\
\hline I & $-0,463^{\mathrm{a}}$ & $-0,409^{\mathrm{a}}$ & $-0,473^{\mathrm{a}}$ & $-0,487^{\mathrm{a}}$ & $-0,464^{\mathrm{a}}$ \\
\hline II & $-0,155^{\mathrm{a}}$ & $-0,212^{\mathrm{a}}$ & $-0,162^{\mathrm{a}}$ & $-0,202^{\mathrm{a}}$ & $-0,184^{\mathrm{a}}$ \\
\hline IV & $0,348^{\mathrm{a}}$ & $0,286^{\mathrm{a}}$ & $0,170^{\mathrm{a}}$ & $0,261^{\mathrm{a}}$ & $0,184^{\mathrm{a}}$ \\
\hline $\mathrm{V}$ & $0,749^{\mathrm{a}}$ & $0,705^{\mathrm{a}}$ & $0,646^{\mathrm{a}}$ & $0,663^{\mathrm{a}}$ & $0,565^{\mathrm{a}}$ \\
\hline \multicolumn{6}{|c|}{ Type of settlement (regional center) } \\
\hline City & $-0,124^{\mathrm{a}}$ & $-0,127^{\mathrm{a}}$ & $-0,170^{\mathrm{a}}$ & $-0,095^{b}$ & $-0,069$ \\
\hline Urbansettlement & $-0,037$ & $-0,143^{\mathrm{c}}$ & $-0,119^{\mathrm{a}}$ & $-0,60$ & 0,089 \\
\hline Village & $-0,287^{\mathrm{a}}$ & $-0,249^{\mathrm{a}}$ & $-0,317^{\mathrm{a}}$ & $-0,219^{\mathrm{a}}$ & $-0,234^{\mathrm{a}}$ \\
\hline \multicolumn{6}{|c|}{ Demographic type of household (Households without children) } \\
\hline Lonely & $0,343^{\mathrm{a}}$ & $0,271^{\mathrm{a}}$ & $0,175^{\mathrm{a}}$ & $0,163^{\mathrm{b}}$ & $0,217^{b}$ \\
\hline Householdswithchildren & 0,120 & 0,002 & $-0,013$ & 0,041 & 0,038 \\
\hline $\begin{array}{l}\text { Single-parent families and other types of } \\
\text { households }\end{array}$ & 0,081 & 0,015 & 0,038 & 0,067 & 0,066 \\
\hline The number of children up to 3 years & $-0,110^{b}$ & $-0,172^{b}$ & $-0,091^{b}$ & $-0,040$ & $-0,023$ \\
\hline - from 3 to 7 years & $-0,185^{\mathrm{a}}$ & $-0,037$ & $-0,018$ & $-0,111^{b}$ & $-0,041$ \\
\hline - from7to18years & $-0,083^{b}$ & $-0,139$ & 0,014 & $-0,014$ & $-0,040$ \\
\hline Numberofpensioners & $-0,060^{b}$ & $-0,089^{b}$ & $-0,046^{\mathrm{c}}$ & $-0,068^{\mathrm{a}}$ & $-0,104^{\mathrm{a}}$ \\
\hline \multicolumn{6}{|c|}{ Types of loans (consumer and others) } \\
\hline Mortgage & $0,126 \mathrm{~b}$ & $-0,199^{\mathrm{b}}$ & 0,008 & $-0,081$ & $-0,018$ \\
\hline Car & $0,246^{\mathrm{a}}$ & $0,167^{\mathrm{a}}$ & $0,163^{\mathrm{b}}$ & $0,240^{\mathrm{a}}$ & $0,281^{\mathrm{a}}$ \\
\hline \multicolumn{6}{|c|}{ The number of loans (more than one) } \\
\hline One loan & 0,012 & $-0,007$ & $0,074 \mathrm{~b}$ & 0,018 & $0,217^{\mathrm{b}}$ \\
\hline Creditload & $0,046^{\mathrm{b}}$ & 0,018 & $-0,438^{\mathrm{a}}$ & $0,007^{b}$ & $-0,900^{\mathrm{a}}$ \\
\hline Creditloadsquare & $-0,0007$ & 0,004 & $0,081^{\mathrm{a}}$ & $-0,000^{b}$ & $0,384^{\mathrm{a}}$ \\
\hline $\begin{array}{l}\text { Cash costs and savings }>\text { disposable } \\
\text { resources }\end{array}$ & $0,554^{\mathrm{a}}$ & $0,620^{\mathrm{a}}$ & $0,596^{\mathrm{a}}$ & $0,579^{\mathrm{a}}$ & $0,573^{\mathrm{a}}$ \\
\hline Const. & 8,037 & 8,547 & 8,638 & 9,033 & 9,472 \\
\hline Pseudo $\mathrm{R}^{2}$ & 0,525 & 0,528 & 0,549 & 0,496 & 0,478 \\
\hline
\end{tabular}

In general, the trends identified in the interpretation of the models have been preserved, but the nature of the credit load has changed. The sign of the regression coefficient during periods of economic growth became positive, the percentage impact on disposable resources was weaker and amounted to a fraction of a percent, but statistically significant. During the period of economic downturns (2009 and 2014), the sign with the coefficient of the credit load changed to negative, and began to have a noticeable effect on the reduction of consumer spending.

The decline of the graph line in 2009 and 2014 shows in "Fig. 1" the undoubted effect of crisis processes on the ratio of incomes and expenses in households, which is that in these periods the share of households with hidden incomes decreases [6]. The explanation for this may be that during the crisis period, the number of sources of informal income is reduced, and in addition, some households begin to spend savings and loans, to save less for future use. The percentage of households in which current consumer spending exceeded disposable resources varied in the study period from $22 \%$ to $31 \%$, and if we take into account that total expenditures and savings exceed income, then the share of such households was still about $10 \%$ above.

These facts, in turn, were reflected in the estimates of the models presented in "Table I" and "Table II". The result indicates that cash expenditures are a more reliable indicator of household welfare, since they implicitly include borrowed, non-declared funds, the attraction of which allows smooth household consumption.

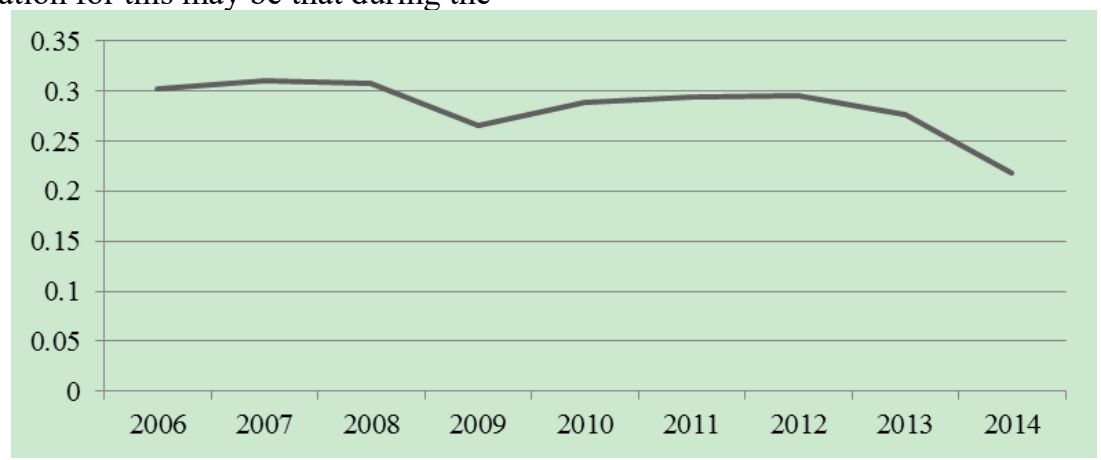

Fig. 1. Proportion of households with consumer spending in excess of disposable resources. 
According to the results of models evaluation, it can be seen that expected consumer spending in households, where expenditures exceeded income, was more than 50\% higher, but declined during periods of economic recessions.

\section{CONCLUSION}

The identified phenomenon, in our opinion, reveals one of the characteristic features of the credit behavior of Russians. The overwhelming share of household loan payments serves consumer loans, which are basically shortterm. The huge credit load of households in Western countries is compensated by the duration of their repayment and low payment for loans. For a significant part of Russian households, especially with children, loans increase the credit load to critical values, which threaten the impossibility of their repayment and the reduction of expenses for vital needs. And in this situation, smoothing the impact of the credit burden on consumer spending occurs by attracting additional resources. At the same time, the question remains whether these resources are loans or hidden incomes. If we assume that a significant part of these funds are simply incomes that were not indicated in the survey, then it is reasonable to calculate the ratio of the credit load at the micro level as the ratio of the amount of credit debt to household expenditures [7].

\section{REFERENCES}

[1] Central Bank of the Russian Federation. Indicators of credit institutions. [Electronic resource] URL: https://www.cbr.ru/statistics/?PrtId=pdko_sub

[2] Central Bank of the Russian Federation. The volume of loans, deposits and other funds placed by organizations, individuals and credit organizations. [Electronic resource] URL: https://www.cbr.ru/statistics/print.aspx?file=bank system/4-31_18.htm\&pid=pdko_sub\&sid=dopk

[3] Central Bank of the Russian Federation. Information on the risks of lending to individuals in 2018. [Electronic resource] URL: https://www.cbr.ru/statistics/print.aspx?file=bank_system/risk_18.ht m\&pid=pdko_sub\&sid=ITM_60627

[4] L.I. Nivorozhkina. The impact of consumer lending on the conditions of the formation of human capital in children from low-income families // Accounting and statistics. №1 (37), 2015. P.88-94.

[5] "Russian Monitoring of the Economic Situation and Health of the HSE (RLMS-HSE)", conducted by the National Research University "Higher School of Economics" and "Demoscope" with the participation of the Population Center of the University of North Carolina in Chapel Hill and the Institute of Sociology of the Federal Scientific- research sociological center of the Russian Academy of Sciences. [Electronic resource] URL: http://www.cpc.unc.edu/projects/rlms , http://www.hse.ru/rlms

[6] L.I. Nivorozhkina. Hidden household incomes: empirical analysis experience // Terra Economicus. 2016. Vol. 14. No. 4. P. 42-53.

[7] L.I. Nivorozhkina. The impact of lending on household consumption: an economic and statistical study // Statistics Questions, №1, 2016. P.47-54. 